ISSN : 2721-074X (Online) - 2301-6698 (Print)

Available on : http://ejournal.utp.ac.id/index.php/AFP/index

This is Under CC BY SA Licence

\title{
UJI EFIKASI INSEKTISIDA BAHAN AKTIF PERMETRIN 300 g/l TERHADAP POPULASI HAMA ULAT DAUN (Plutella xylostella L) PADA TANAMAN KUBIS (Brassica oleracea)
}

\section{Effication Test of Active Material Insecticides Permetrin $300 \mathrm{~g} / \mathrm{l}$ on Leaf Caterpillar Pest Population (Plutella Xylostella L) in Cabbage Plant (Brassica Oleracea)}

\author{
Joko Kusnanto, Tyas Soemarah K.D*., Agus Budiono, Endang Suprapti, dan Haryuni \\ Program Studi Agroteknologi, Fakultas Pertanian, Universitas Tunas Pembangunan \\ Surakarta \\ Corresponden author : tskdmp@gmail.com
}

\begin{abstract}
Cabbage production in the last six years shows a trend of fluctuations every year. Production in 2012 increased by $0.14 \%$ to 7,550,021 tons from 7,539,533 tons, then increased by $1.95 \%$ to 7,469,013 tons in 2013, and decreased 3.06\% to 7,461,697 tons in 2014, then in 2015 it decreased $2.62 \%$ to 7,265,840 tons, then in 2016 the production increased to 7,274,126 tons and subsequently in 2017 it increased 2.64\%. Fluctuations in cabbage production are inseparable from the effect of an increase or decrease in the area of harvest and the attack of plant pests. The aim of this study was to determine the most effective concentration of the active ingredient of Permethrin $300 \mathrm{~g} /$ to control Plutella xylostella L caterpillar pest in cabbage plants. This research was conducted in Sudimoro Village, Teras Subdistrict, Boyolali Regency at an altitude of $196 \mathrm{~m}$ above sea level with alluvial brown soil types, with soil solum thickness $>90 \mathrm{~cm}$. Based on the Oldeman classification, Sudimoro Village is a D3 zone, with a wet month length of 3-4 months and a dry month length of 3-6 months. The method used in the study was a non factorial Complete Group Randomized Design (RAKL) with 5 (five) different concentrations of insecticide treatments. The concentration treatments used were $1 \mathrm{cc} /$ liters $\left(C_{1}\right), 0.75 \mathrm{cc}$ liters $\left(C_{2}\right), 0.5 \mathrm{cc}$ liters $\left(C_{3}\right), 0.25 \mathrm{cc}$ liters $\left(C_{4}\right)$, and control $\left(C_{5}\right)$. The results showed that the treatment of the active ingredient concentration of insecticide Permethrin $300 \mathrm{~g} / \mathrm{l}$ had a very significant effect on the parameters of the Plutella xylostella L population, the weight of the wet stover, the weight of the crop, and the diameter of the crop. However, it does not significantly affect the parameters of plant height and dry stover weight.The effectiveness of the active ingredient insecticide Permethrin $300 \mathrm{~g} / \mathrm{l}$ in the parameters of the population of Plutella xylostella $L$ is best in the treatment concentration of $0.75 \mathrm{cc}$ liters $\left(C_{2}\right)$, with a $100 \%$ efficacy rate.
\end{abstract}

Keywords: cabbage, insecticide, permethrin, Plutella xylostella L.

\section{ABSTRAK}

Produksi kubis dalam enam tahun terakhir menunjukkan tren fluktuasi setiap tahun. Produksi pada tahun 2012 meningkat sebesar $0,14 \%$ menjadi 7.550 .021 ton dari 7.539 .533 ton, kemudian meningkat $1,95 \%$ menjadi 7.469.013 ton pada 2013, dan menurun 3,06\% menjadi 7.461.697 ton pada 2014, kemudian pada 2015 turun 2,62\% menjadi 7.265.840 ton, kemudian pada 2016 produksi meningkat menjadi 7.274.126 ton dan kemudian pada 2017 meningkat 2,64\%. Fluktuasi produksi kubis tidak dapat dipisahkan dari efek peningkatan atau penurunan area panen dan serangan hama tanaman. Tujuan dari penelitian ini adalah untuk menentukan konsentrasi yang paling efektif dari bahan aktif Permethrin $300 \mathrm{~g} / 1$ untuk mengendalikan hama ulat Plutella xylostella L pada tanaman kubis. Penelitian ini dilakukan di Desa Sudimoro, Kecamatan Teras, Kabupaten Boyolali pada ketinggian $196 \mathrm{~m}$ di atas permukaan laut dengan jenis tanah aluvial coklat, dengan ketebalan solum tanah> $90 \mathrm{~cm}$. Berdasarkan klasifikasi Oldeman, Desa Sudimoro adalah zona D3, dengan panjang bulan basah 3-4 bulan dan panjang bulan kering 3-6 bulan. Metode yang digunakan dalam penelitian ini adalah Rancangan Acak Kelompok Lengkap (RAKL) nonfaktorial dengan 5 (lima) konsentrasi perlakuan 


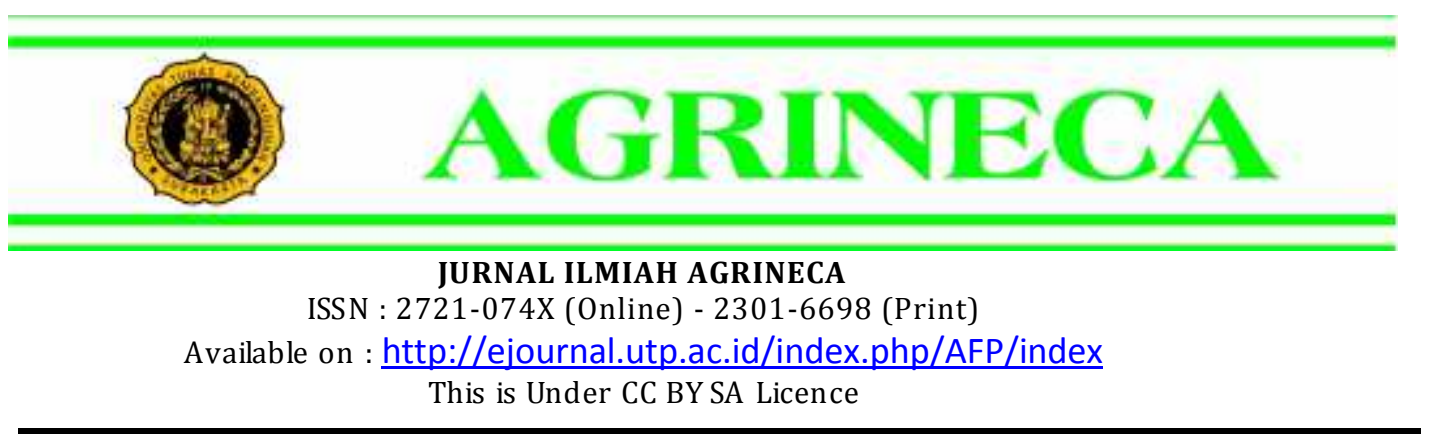

insektisida yang berbeda. Perlakuan konsentrasi yang digunakan adalah $1 \mathrm{cc} /$ liter (C1), 0,75 cc / liter (C2), 0,5 cc / liter (C3), 0,25 cc / liter (C4), dan kontrol (C5). Hasil penelitian menunjukkan bahwa perlakuan konsentrasi bahan aktif insektisida Permethrin $300 \mathrm{~g} / 1$ memiliki pengaruh yang sangat signifikan terhadap parameter populasi Plutella xylostella L, bobot brangkasan basah, bobot tanaman, dan diameter tanaman. tanaman. Namun, itu tidak secara signifikan mempengaruhi parameter tinggi tanaman dan berat brangkasan kering. Efektivitas bahan aktif insektisida Permethrin $300 \mathrm{~g} / 1$ dalam parameter populasi Plutella xylostella $\mathrm{L}$ adalah yang terbaik dalam konsentrasi perlakuan $0,75 \mathrm{cc} /$ liter $(\mathrm{C} 2)$, dengan tingkat kemanjuran $100 \%$.

Kata kunci: kol, insektisida, permetrin, Plutella xylostella L

\section{PENDAHULUAN}

Tanaman kubis (Brassica oleracea) merupakan salah satu sayuran yang banyak dibudidayakan oleh petani di Indonesia, baik di dataran tinggi maupun dataran rendah. Tanaman kubis biasanya dibudidayakan pada awal musim kemarau. Kubis memiliki potensi produksi yang tinggi dan pemasarannya relatif mudah. Sehingga tepat jika kubis diprioritaskan sebagai salah satu tanaman sayuran daun yang perlu dikembangkan lebih lanjut (Pracaya, 2001).

Produksi kubis dalam enam tahun terakhir ini menunjukkan trend fluktuasi setiap tahunnya. Produksi pada tahun 2012 mengalami peningkatan $0,14 \%$ menjadi 7.550.021 ton dari 7.539.533 ton, selanjutnya meningkat $1,95 \%$ menjadi 7.469 .013 ton di tahun 2013, dan menurun 3,06\% menjadi 7.461 .697 ton tahun 2014, selanjutnya tahun 2015 menurun $2,62 \%$ menjadi 7.265 .840 ton, kemudian di tahun 2016 produksinya meningkat menjadi 7.274.126 ton dan selanjutnya pada tahun 2017 meningkat $2,64 \%$. Fluktuasi produksi kubis tidak terlepas dari pengaruh peningkatan maupun penurunan pada luas panen (Anonim, 2017).

Penyebab lainnya yang tidak kalah penting adalah adanya serangan hama dan penyakit tanaman. Beberapa jenis hama dan penyakit dapat menyebabkan kehilangan hasil yang cukup tinggi.

Salah satu hama penting tanaman kubis yang sangat merugikan dan merusak, terutama pada musim kemarau adalah Ulat Daun (Plutella xylostella L)(Lepidoptera: Plutellidae). Apabila tidak ada tindakan pengendalian, hama ini dapat menyebabkan kerusakan tanaman sejak fase pembibitan sampai dengan pembentukan krop. Serangan yang berat dapat menyebabkan daun-daun tanaman kubis menjadi rusak, sehingga tanaman tidak dapat membentuk krop dan panennya menjadi gagal. Serangan ulat daun kubis $P$. xylostella $L$ bersama ulat jantung kubis Cocidolomia pavonana $F$ mampu menyebabkan kerusakan berat dan dapat menurunkan produksi kubis. Kondisi ini tentu saja menjadi kekhawatiran tersendiri bagi petani, sehingga diperlukan upaya pengendalian yang tepat untuk mencegah dan menekan kerugian akibat serangan hama tersebut (Sastrosiswoyo,S.dan

W.Setiawati,1993).

Sampai saat ini sebagian besar petani di Indonesia masih tergantung pada penggunaan insektisida sintetik untuk mengendalikan hama ulat daun Plutella xylostella $L$. Penggunaan insektisida sintetik sangat diminati oleh petani karena mudah dalam aplikasi dan dapat mengendalikan hama dalam waktu singkat (Prijono, 1998). Salah satu bahan aktif yang sering digunakan petani dalam pengendalian yaitu Permetrin.

Permetrin adalah bahan kimia sintetis atau buatan yang banyak dimanfaatkan sebagai bahan insektisida atau bahan anti serangga, dengan cara kerja sebagai racun kontak. Bahan aktif permetrin memiliki sifat neurotoxic yang dapat merusak jaringan syaraf dari organisme sasaran. Akibatnya, serangga sasaran akan mengalami kematian dengan cepat. Sifat ini menjadikan permetrin sebagai produk anti serangga yang banyak diminati oleh masyarakat (Priyono, 1998).

\section{METODE PENELITIAN}


This is Under CC BY SA Licence

pembanding (taraf nyata 5\%) dan atau populasi hama sasaran atau tingkat kerusakan tanaman pada petak perlakuan insektisida yang diuji nyata lebih rendah daripada populasi hama atau tingkat kerusakan tanaman pada petak kontrol (taraf nyata 5\%).

\section{HASIL DAN PEMBAHASAN}

\section{Populasi Plutella xylostella $L$}

Hasil analisis sidik ragam menunjukkan bahwa perlakuan konsentrasi insektisida bahan aktif Permetrin 300g/l memberikan pengaruh sangat nyata pada parameter populasi Plutella xylostella $L$.

Untuk mengetahui adanya pengaruh masing-masing perlakuan konsentrasi insektisida bahan aktif Permetrin $300 \mathrm{~g} / \mathrm{l}$ terhadap populasi Plutella xylostella $L$, dilakukan uji jarak berganda Duncan's 5\% yang disajikan pada tabel 1 di bawah ini.

Tabel 1. Pengaruh konsentrasi insektisida bahan aktif Permetrin $300 \mathrm{~g} / \mathrm{l}$ terhadap populasi Plutella xylostella $L$

\begin{tabular}{cc}
\hline $\begin{array}{c}\text { Perlakuan } \\
\text { (treatment) }\end{array}$ & Rerata populasi Plutella xylostella L (ekor) \\
\hline Konsentrasi Insektisida Bahan Aktif Permetrin $300 \mathrm{~g} / \mathrm{l}$ & \\
\hline $\mathrm{C}_{1}$ & $0,40 \mathrm{a}$ \\
$\mathrm{C}_{2}$ & $\mathbf{0 , 0 0 a}$ \\
$\mathrm{C}_{3}$ & $0,40 \mathrm{a}$ \\
$\mathrm{C}_{4}$ & $6,00 \mathrm{~b}$ \\
$\mathrm{C}_{5}$ & $\mathbf{8 , 8 0 b}$
\end{tabular}

Keterangan: Perlakuan yang diikuti dengan satu huruf yang sama menunjukkan berbeda tidak nyata pada taraf 5\% uji jarak berganda Duncan's.

Tabel 1 Uji Jarak Berganda Duncan 5 $\%$, menunjukkan perbedaan yang tidak nyata pada perlakuan konsentrasi $1 \mathrm{cc} /$ liter $\left(\mathrm{C}_{1}\right)$; $0,75 \mathrm{cc} /$ liter $\left(\mathrm{C}_{2}\right)$; dan $0,5 \mathrm{cc} /$ liter $\left(\mathrm{C}_{3}\right)$, dengan rerata populasi masing-masing konsentrasi yaitu 0,40 ekor/ blok; 0,00 ekor/ blok; dan 0,40 ekor/ blok. Perbedaan yang tidak nyata juga ditunjukkan pada perlakuan konsentrasi $0,25 \mathrm{cc} /$ liter $\left(\mathrm{C}_{4}\right)$ dan petak kontrol $\left(\mathrm{C}_{5}\right)$ dengan rerata populasi masingmasing 6,00 ekor/ blok dan 8,80 ekor/ blok. Akan tetapi dari perlakuan $\mathrm{C}_{1}, \mathrm{C}_{2}$, dan $\mathrm{C}_{3}$ menunjukkan perbedaan yang nyata dengan perlakuan $\mathrm{C}_{4}$ dan kontrol. Rerata populasi terendah terdapat pada perlakuan $\mathrm{C}_{2}$ yaitu 0,00 ekor/ blok, sedangkan populasi tertinggi terdapat pada petak kontrol yaitu 8,80 ekor/ blok.

Efektifitas insektisida terhadap hama sasaran sangat dipengaruhi oleh aplikasi yang memperhatikan prinsip 5 (lima) tepat, yaitu: a) Tepat sasaran, dengan cara menentukan jenis tanaman dan hama yang akan dikendalikan. Ulat daun Plutella xylostella termasuk dalam golongan insecta (serangga) yang harus dikendalikan dengan insektisida. Karakteristik hama ini menyerang daun tanaman kubis dimulai dari bagian bawah daun. Oleh karena itu, aplikasi insektisida dimulai dari bagian bawah daun kubis.

b) Tepat jenis, dengan cara menentukan jenis pestisida dan bahan aktif yang digunakan. Bahan aktif Permetrin 300 $\mathrm{g} / \mathrm{l}$ termasuk dalam golongan insektisida Piretroid sintetic yang mengganggu sistem syaraf serangga dengan cara mengikat protein yang mengatur denyut impul syaraf. Efeknya impul syaraf akan mengalami stimulasi secara terus menerus dan mengakibatkan serangga 
This is Under CC BY SA Licence

menunjukkan gejala tremor/ gemetar, gerakan tak terkendali, dan akhirnya mengalami kematian. Insektisida bahan aktif Permetrin $300 \mathrm{~g} / \mathrm{l}$ termasuk insektisida racun kontak yang dapat membunuh sasaran jika terjadi kontak langsung dengan serangga tersebut.

c) Tepat waktu, ditentukan berdasarkan tahap rentan dari hama yang menyerang dan kondisi cuaca pada saat aplikasi. Jika dikaitkan dengan tahap perkembangan hama, aplikasi pada saat penelitian menggunakan sistem kalender yaitu aplikasi terjadwal setiap 1 (satu) minggu sekali. Aplikasi yang dilaksanakan dengan sistem kalender dapat membunuh sasaran pada fase larva maupun imago, karena tidak berpedoman pada siklus hidup hama. Dilihat dari kondisi cuaca, setelah aplikasi yang dilaksanakan pada pagi hari terjadi hujan pada siang dan sore hari. Akan tetapi hal ini tidak memberikan pengaruh secara signifikan terhadap efektifitas insektisida bahan aktif Permetrin $300 \mathrm{~g} / \mathrm{l}$, dibuktikan dengan kematian hama sasaran yang diamati 1 (satu) hari setelah aplikasi dilaksanakan.

d) Tepat dosis dan konsentrasi, dilakukan dengan 4 (empat) taraf konsentrasi yang berbeda. Hasilnya, konsentrasi insektisida bahan aktif Permetrin $300 \mathrm{~g} / \mathrm{l}$ yang paling baik digunakan untuk mengendalikan hama Plutella xylostella $L$ adalah $0,75 \mathrm{cc} /$ liter, dibuktikan dengan kematian populasi yang mencapai $100 \%$ pada akhir pengamatan.

e) Tepat cara, dengan memperhatikan bentuk formulasi pestisida dan cara aplikasinya. Insektisida bahan aktif permetrin $300 \mathrm{~g} / \mathrm{l}$ memiliki bentuk formulasi Emulsible Concentrate (EC). Sebelum diaplikasikan, insektisida terlebih dahulu dicampur dengan air, diaduk rata, dan cara aplikasi dengan disemprotkan.
(Sitompul P.,1987)

Selain faktor diatas, efektifitas insektisida terhadap hama sasaran dipengaruhi oleh faktor genetis dari hama tersebut. Satu jenis bahan aktif pestisida yang diaplikasikan secara terus menerus dapat menyebabkan resistensi dari hama sasaran. Akan tetapi hal tersebut tidak terjadi pada penelitian ini, dibuktikan dengan adanya kematian yang signifikan terhadap hama Plutella xylostella $L$ pada tiap-tiap taraf konsentrasi setelah dilakukan aplikasi insektisida.

\section{Komponen Pertumbuhan}

Hasil analisis sidik ragam menunjukan bahwa perlakuan konsentrasi insektisida bahan aktif Permetrin 300 g/l tidak memberikan perbedaan nyata terhadap rerata tinggi tanaman dan berat brangkasan kering. Akan tetapi memberikan perbedaan yang sangat nyata terhadap rerata berat brangkasan segar.

Untuk mengetahui adanya pengaruh berbagai taraf konsentrasi insektisida bahan aktif Permetrin $300 \mathrm{~g} / 1$ terhadap komponen pertumbuhan, dilakukan uji jarak berganda Duncan's 5\% yang disajikan pada tabel 2. di bawah ini. 


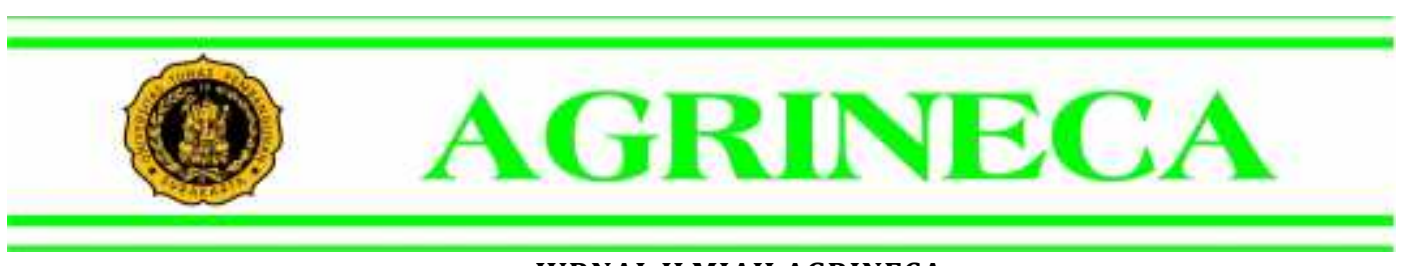

JURNAL ILMIAH AGRINECA

ISSN : 2721-074X (Online) - 2301-6698 (Print)

Available on : http://ejournal.utp.ac.id/index.php/AFP/index

This is Under CC BY SA Licence

perlakuan konsentrasi insektisida bahan aktif Permetrin $300 \mathrm{~g} / \mathrm{l}$ pada perlakuan $\mathrm{C}_{1}(1 \mathrm{cc} / \mathrm{liter})$ tidak berbeda nyata dengan perlakuan $\mathrm{C}_{2}(0,75 \mathrm{cc} /$ liter) dan $\mathrm{C}_{3}(0,5 \mathrm{cc} /$ liter $)$, akan tetapi berbeda nyata dengan perlakuan $\mathrm{C}_{4}(0,25 \mathrm{cc} / \mathrm{liter})$ dan $\mathrm{C}_{5}$ (kontrol). Rerata berat brangkasan segar yang paling rendah terdapat pada perlakuan kontrol $\left(\mathrm{C}_{5}\right)$ yaitu 522,42 gram. Sedangkan Rerata berat brangkasan segar yang paling tinggi terdapat pada perlakuan konsentrasi $0,5 \mathrm{cc} /$ liter $\left(\mathrm{C}_{2}\right)$ yaitu 748,62 gram.

Menurut Dwidjoseputro (1986), bahwa tersedianya hara tanah yang cukup dan lingkungan tumbuh yang mendukung akan berdampak pada pertumbuhan tanaman. Seperti halnya dengan berat segar tanaman, dikatakan sangat dipengaruhi oleh unsur $\mathrm{N}$ yang diserap tanaman, kadar air dan kandungan unsur hara yang ada dalam sel-sel jaringan tanaman.

Berat brangkasan segar ini juga dipengaruhi adanya unsur $\mathrm{P}$ dalam pupuk NPK pada saat pemupukan awal dan susulan. Unsur P berfungsi sebagai pertumbuhan akar, pembungaan, pemasakan buah atau biji. Selain itu, unsur $\mathrm{P}$ juga berfungsi untuk penyusunan inti sel, lemak dan protein. Penyerapan unsur $\mathrm{P}$ oleh tanaman ini distimulir atau didorong oleh keberadaan unsur hara mikro yang terdapat pada pupuk organik dan unsur hara mikro dari alam, dimana peran unsur mikro seperti $\mathrm{Mn}, \mathrm{Fe}, \mathrm{Zn}$, dan $\mathrm{Mg}$ adalah sebagai kofaktor enzim yang mendorong peningkatan aktivitas metabolisme di dalam tubuh tanaman (Pranata, 2004).

Penyebab lainnya adalah penggunaan insektisida bahan aktif Permetrin 300 g/l yang mampu menurunkan tingkat serangan hama, sehingga berpengaruh pada peningkatan pertumbuhan daun. Hal ini dapat dibuktikan dari berat brangkasan pada petak kontrol yang paling rendah, disebabkan oleh serangan Plutella xylostella $L$ yang merusak sebagian besar daun tanaman kubis.

Tabel 2. Uji Jarak Berganda Duncan's pada parameter berat brangkasan kering menunjukkan perlakuan konsentrasi insektisida bahan aktif Permetrin $300 \mathrm{~g} / \mathrm{l}$ dengan berbagai taraf konsentrasi tidak memberikan perbedaan yang nyata terhadap rerata berat brangkasan kering. Rerata berat brangkasan kering yang paling rendah terdapat pada perlakuan kontrol $\left(\mathrm{C}_{5}\right)$ yaitu 50,82 gram. Sedangkan rerata berat brangkasan kering yang paling tinggi terdapat pada perlakuan konsentrasi $0,75 \mathrm{cc} /$ liter $\left(\mathrm{C}_{2}\right)$ yaitu 55,70 gram.

Berat brangkasan kering sangat berkaitan dengan hasil pada brangkasan segar. Residu bahan aktif permetrin $300 \mathrm{~g} / \mathrm{l}$ diduga tidak berpengaruh terhadap berat tanaman segar maupun setelah dikeringkan.

\section{Komponen Hasil}

Hasil analisis sidik ragam menunjukan bahwa perlakuan konsentrasi insektisida bahan aktif Permetrin $300 \mathrm{~g} / \mathrm{l}$ memberikan perbedaan yang sangat nyata terhadap rerata berat krop dan diameter krop.

Untuk mengetahui adanya pengaruh berbagai taraf konsentrasi insektisida bahan aktif Permetrin $300 \mathrm{~g} / \mathrm{l}$ terhadap komponen hasil, dilakukan uji jarak berganda Duncan's 5\% yang disajikan pada tabel 3. di bawah ini.

Tabel 3. Pengaruh konsentrasi insektisida bahan aktif Permetrin $300 \mathrm{~g} / \mathrm{l}$ terhadap komponen hasil

\begin{tabular}{ccc}
\hline \multirow{2}{*}{$\begin{array}{c}\text { Perlakuan } \\
\text { (treatment) }\end{array}$} & $\begin{array}{c}\text { Rerata Berat Krop } \\
(\mathrm{g})\end{array}$ & $\begin{array}{c}\text { Rerata Diameter Krop } \\
(\mathrm{cm})\end{array}$ \\
\cline { 2 - 3 } & & \\
$\mathrm{C}_{1}$ & $1013,20 \mathrm{~b}$ & $14,71 \mathrm{~b}$ \\
$\mathrm{C}_{2}$ & $\mathbf{1 0 5 5 , 4 0 b}$ & $15,24 \mathrm{bc}$ \\
$\mathrm{C}_{3}$ & $1010,00 \mathrm{~b}$ & $\mathbf{1 5 , 4 7 c}$ \\
\hline
\end{tabular}




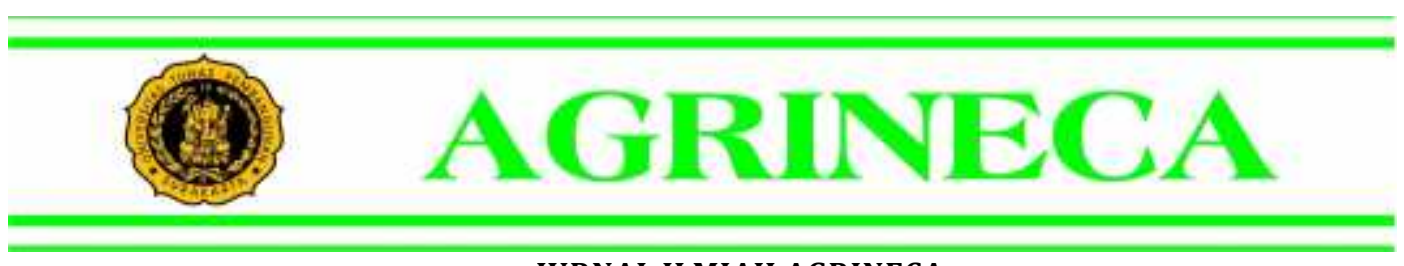

JURNAL ILMIAH AGRINECA

ISSN : 2721-074X (Online) - 2301-6698 (Print)

Available on : http://ejournal.utp.ac.id/index.php/AFP/index

This is Under CC BY SA Licence

Untuk mengendalikan hama Plutella xylostella $L$ pada tanaman kubis, dapat menggunakan insektisida bahan aktif Permetrin 300 $\mathrm{g} / \mathrm{l}$ dengan konsentrasi paling efektif sebanyak 0,75 $\mathrm{cc} /$ liter.

\section{DAFTAR PUSTAKA}

Anonim. 2018. Insektisida. https://id.wikipedia.org/wiki/Insektisida. Diakses pada tanggal 16 Juli 2018.

Arief, Arifin. 1990. Hortikultura. Andy Offset. Yogyakarta.

Arikunto, Suharsimi. 2002. Prosedur Penelitian-Suatu Pendekatan Praktek. PT Rineka Cipta. Jakarta.

Balse. 1985. Field Trial Manual. Ciba. Geigy. Switzerland.

Darjanto dan S. Satifah. 1990. Pengetahuan Dasar Biologi Bunga dan Tekniik Penyerbukan Silang Buatan. PT Gramedia. Jakarta.

Dwidjoseputro. 1986. Biologi. Erlangga. Jakarta.

Hakim, et al..1986. Dasar-Dasar Ilmu Tanah. Universitas Lampung. Lampung.

Hariyadi, B. W., Huda, N., Ali, M., \& Wandik, E. (2019). The Effect of Tambsil Organic Fertilizer on The Growth And Results of Onion (Allium Ascalonicum L.) In Lowland. Agricultural Science, 2(2), 127-138.

Indranada, H. K. 1986. Pengelolaan Kesuburan Tanah. Bina Aksara. Jakarta.

Kalshoven, L. G. E,. 1981. The Pest of Crops in Indonesia. Revised and Translated By P.A. Van der laan. PT. Ichtiar Baru-Van Hoeve. Jakarta.

Kementrian Pertanian. 2017. Laporan Kinerja Dirjen Hortikutura Tahun 2017. Kementrian Pertanian.

Menteri Pertanian. 2003. Keputusan Menteri Pertanian No:445/kpts/sr:140/9/2003 tentang pendaftaran dan pemberian izin tetap bahan teknis pestisida. Kementrian pertanian. Jakarta.

2007. Peraturan Menteri Pertanian No:07/SR.140/2/2007 tentang syarat dan tata cara pendaftaran pestisida. Kementerian Pertanian. Jakarta.

Permadi, A.H., dan S.Sastrosiswojo. 1993. Kubis. Badan Penelitian dan Pengembangan Pertanian Balai Penelitian Hortikultura. Lembang.

Pracaya. 2001. Kol Alias Kubis. Penebar Swadaya, Jakarta.

Pranata, A.S. 2004. Pupuk Organik Cair Aplikasi dan Manfaatnya. Agromedia Pustaka. Jakarta.

Prijono, D. 1998. Insecticidal activity of meliaceous seed extarcts against Crocidolomia binotalis Zeller (Lepidoptera: Pyralidae). Bul. Hama dan Penyakit Tumbuhan. 10. 1-7.

Rukmana, R. 1994. Budidaya Kubis Bunga \& Broccoli. Kanisius, Yogyakarta.

Sastrsiswojo, S dan W. Setiawati. 1993. Hama-hama Tanaman Kubis dan Cara Pengendalian. Balai Penelitian Hortikultura Lembang.

Sastrosupadi, A. 2000. Rancangan Percobaan Praktis Bidang Pertanian. Kanisius. Malang.

Sitompul, P. 1987. Penggunaan Pestisida Secara Tepat Dan Aman. Kanwil Dep. Kes Sumut. Medan.

Sudarmo, S. 1991. Pestisida. Kanisius. Yogyakarta.

Sudarwohadi. 1992. Metode Pengambilan Sampel. Materi pelatihan PHT di Bandung.

Sugiharyanto. 2007. Geografi dan Sosiologi. Yudhistira. Jakarta.

Sumiati, E. 2006. Pertumbuhan Serta Hasil Tanaman Kubis Putih Dengan Aplikasi Pupuk NPK. Balai Penelitian Tanaman Sayuran. Lembang.

Syahri. 2017. Penggunaan Pestisida Secara Tepat dan Bijaksana. Artikel. Balitbangtan. Kementrian Pertanian.

Udiarto, B.K dan S. Sastrosiswojo. 1997. Selektifitas Beberapa Jenis Insektisida Terhadap Larva Plutella xylostella L. dan Parasitoid Imago Diadegma sumiclausum Helln. Jur. Hort.7 (3): $810-817$.

Untung, K. 1993. Konsep dan Penerapan Pengendalian Hama Terpadu. Andi Offset. Yogyakarta. 